\title{
Five Factors Influencing the Students' Motivation to Learn English as a Foreign Language: A Closer Look into Montessori Classroom Environment
}

\author{
Febti Mahani Batubara ${ }^{1}$, Tatum Derin ${ }^{2}$, Nunung Susilo Putri ${ }^{3}, \&$ Ratih Saltri Yudar ${ }^{4}$ \\ ${ }^{1}$ Universitas Lancang Kuning, Pekanbaru, Indonesia \\ ${ }^{3}$ SMU Negeri 3, Pekanbaru, Indonesia \\ ${ }^{2,4}$ U-RAISE Academy, Pekanbaru, Indonesia \\ febtibatubara0802@gmail.com
}

ARTICLE HIST
Received $: 2019-08-24$
Revised $: 2020-01-09$
Accepted $:$ 2020-08-26

\section{KEYWORDS}

Motivation

Montessori Method

Classroom Environment

Elementary School

English as a Foreign Language

\begin{abstract}
Good learning environment will bring out qualified students. This study focuses on the Montessori method, which is an approach of education designed to train the students' independence in learning. The study uses descriptive quantitative research design to describe the factors of Montessori classroom environment on the motivation of students in Royal Prime Montessori Elementary School Pekanbaru in academic year 2018/2019. The sample of study is 55 students selected from five classes. The data were collected using questionnaire and observation checklist. This study found five factors influencing the students' motivational condition, i.e., teacher's presence, personal attitude, Montessori materials, classroom conditions and friends' influence. This study revealed that the students taught with this method are active and cooperative during their English learning activities.
\end{abstract}

\section{Introduction}

School isn't always the most exciting place for young kids to be, so teachers need to set the classroom environment in ways that stimulates the students' motivation. Arguably, classroom environment is the most important factor on students' willingness to even engage with the activities set by the teacher. According to Goos \& Sonnemenn (2017), "a good learning environment raises student expectations, encourages them to participate, and ensures that no student fly under the radar." Qualified students come from good learning environment. Therefore, the factors in classroom environment greatly influence students' motivation during learning activities.

Motivation is the energy that can stimulate the students' effort to achieve a particular goal. McInerney \& Liem (2008) said, "there are three things to remember about education. The first one is motivation. The second one is motivation. The third one is motivation." The quote means to convey the necessity for teachers to make the students eager, if not enthusiastic, to learn and practice using the language they are learning. The methods that teacher apply in the class will not give or bring a significant impact on the students' achievement if the students do not have the interest to learn (Hamuddin et al., 2020; Nasution, 2019). The teacher also needs to be careful from using new teaching techniques or lesson materials that might trigger the students' anxieties (Derin \& Hamuddin, 2019) or add too much burden on the teacher's part (Junaidi et al., 2020). Classroom environment and motivation cannot be divided. A good classroom environment boosts students' motivation while monotonous classroom environment reduces students' motivation. The teacher needs an appropriate method that creates a comfortable and engaging classroom environment.

Multiple studies advocated that Montessori Method is an effective learning suitable for elementary students as it centres on students and ensures experiential learning, (Salazar, 2014; Handayani, 2014; Scanlan, 2013; Gokhan, 2018). Montessori Method develops the students independence in learning. Montessori classes achieve this by implementing activities that allocate responsibilities to the students' shoulders.

Various countries have established Montessori classes, including the Royal prime Montessori School in Pekanbaru, Indonesia. As previous studies have indicated that the Montessori Method can indeed increase students' motivation in learning activities, this present study is interested to investigate the factors behind the method's success.

\section{Literature Review}

\subsection{The Nature of Motivation in Language Learning}

Motivation is an energy that can stimulate someone 'enthusiasm to get the goal. Motivation cannot be separated with education. It is because motivation determined student' condition, respond and students qualified in language learning activities. According to Alizadeh, Mitra (2016), "Motivation is 
an important factor for explaining the success or failure of any complex task". The first step that teacher should do is motivate the students. It is because students without motivation is meaningless.

In addition, Long, Chunmei., Ming, Zhu. \& Chen, Liping (2013 p. 136) also states that "motivation play an important role in foreign language learning". As we know, teach English as foreign language is not easy. It is because English is not our mother language or official language. Therefore, the students need motivation to support and make them enjoy in their learning process. Furthermore, many strategies of learning in language class are nothing without motivation (Wekke et al : 2017).

Suprijono (2009) states that "motivation to learn is the process that gives the spirit of learning, direction, and persistence of behavior". The teacher' responsibility is increase students' motivation during learning activities in the class. The students who do not get the motivation will easy to get bored. It is because every people need motivation in life to get their achievement especially students.

\subsection{The Nature Language Classroom Environment}

Classroom environment is a place where the teacher and students create the interaction to develop students' ability. Actually, this place help the students to get the basic knowledge such as counting, reading, writing, listening, sharing or asking something, expressing their need or feeling. This place also build students confidence, discipline, responsibility and social skill that will give the impact for students' educational success. According to Habibi, Sofwan, \& Mukminin (2016) state that "Classroom environment plays an important part of students' educational success. Classroom environment is the place to give and get knowledge and good habit".

There are some factors or aspect of classroom environment that influence students' motivational condition in the class. Teacher is the main figure in creating positive atmosphere in the class. According to Rahman (2018) find that "teachers have the highest influence on a students' motivation, followed closely by a students' own attitudes towards learning and then parental influence". Beside it, the physical of learning environment also have significant impact towards the effective learning activity and students' motivational condition. Tanner (2000) also state that "an attractive learning environment, the way furniture is arranged, the lighting used, the ability of wall to absorb sound and floor properties have been identified to affect student achievement".

In addition, the effective learning activities is when teacher able to combine and make good interaction between the lesson, strategy to teach and media of learning. According to Harjali (2017), "thus students can manage, interact, and achieve their learning objectives, facilitated by learning activities based on selected materials, strategies, and media".

\subsection{Teaching English for Young Learners by Using Montessori Method}

English is widely taught as a foreign language, in particular in Indonesia (Rahman, 2018). However, in many schools the way of teaching English somehow has their own uniqueness that makes its different one of them is Montessori school. This school has a long tradition in using the method developed by Italian physician Maria Montessori.

This method prepare the environment where students are free to choose their own interest of learning material. This method used some apparatus such as grammar box, grammar symbol, and picture card to stimulate students desire to understand the lessons in English class. According to Handayani, S (2014), "a new style of learning like Montessori approach enlightens children in learning. The classroom's style, learning while playing with tools, and interesting teachers that belong to Montessori approach make children enjoy learning English language".

The steps in learning activities are: The teacher asks the students to get the materials. Then, the teacher explains about the lesson by using the materials. Next, the teacher asks the students to works with the material itself. Moreover, the materials have self - correcting that help the students to solve the problems independently. These activities can build students motivation, confidence and analytical thinking to complete his/her works. According to Dahlmeier, C (2011), "The materials have an inner aim. Montessori wrote that she did not set out to teach any "subjects". Instead, the child, through active involvement, will develop independence, selfconfidence, attention and critical thinking skills.

In addition, Sensorial activity in Montessori classroom intend to growth and develop the five sense such as; visual, tactile, auditory, gustatory, and olfactory senses on each students. According to Faryadi (2009), "educational learning environment such as Montessori classroom using sensory methods statistically improved students' performance as well as motivated them to learn and continue learning the English Language". The teacher should give many sensorial experiences as possible for young learner. It happened because sensorial activities can develop students' performance, focus, and motivation to learn English. Montessori classroom used sensorial material such as; color tablets (visual), sound cylinders (auditory), Fabrics, rough and smooth boards (tactile), smelling and testing bottle (olfactory and gustatory sense). Sensorial material in Montessori classroom are carefully designed. 
The goal of Montessori is to empower students by natural development. It means allowing student to choose learning activities independently. Automatically it will stimulate students desire to understand the lesson. Furthermore it will build good personality like self-correction. Students will learn to correct their mistakes, and learn from their errors. Montessori students also learn to have responsibility to finish their own work. According to Akhsanova, et al (2016), "the organization of teaching English for preschoolers using Maria Montessori's method significantly increases the effectiveness of English language mastering by children, contributes to the development of their personal qualities, and increases the level of motivation to learning".

\section{Method}

The present study applied descriptive quantitative method which aims to describe factors in Montessori classroom environment that influence students' motivation and students' responses during their learning activities. This research conducted in SD Royal Prime Montessori School Pekanbaru at the second semester from 9 to 17 May 2019 in academic year 2018/2019. This school is selected due to its long history of using Montessori Method in teaching English. The population of the study involved 55 students at primary 1-5 students. If the population is less than 100 people, the sample can be taken all of the population. Hence, this study used total sampling technique involved 55 students selected from five classes in total, it means, every number of population will be selected.

The data were collected using questionnaire and observation checklist. The questionnaire was given to answer the first research question "What factors in Montessori English class that influence students' motivational condition?". Beside it, the observation was did to answer the second research question "What were the students' responds during learning activities in Montessori English class?"

\subsection{Questionnaire}

The early step of this study were collecting data through questionnaire which started by running the questionnaire try out in order to check the validity and reliability of the questionnaire. After finished the try out, the researcher tabulated the score of the students' answers by using SPSS version 22 program. Then, the researcher saw that only 23 questions that have been valid and reliable.

So, the researcher gave 23 questions to 55 students at Royal Prime Montessori Elementary school Pekanbaru. The form of questionnaire was closed format and one type of closed format question that is Likert scale that consists of four choices; absolutely agree, agree, disagree, and absolutely disagree. Therefore, the students were able to select one of the choices based on their opinion or feeling in Montessori English class. Each choice has score to analyse the data of the questionnaire. When collecting data, the researcher explained the procedure to finish the questionnaire and help some of student to understand the question. The questionnaire consists of four indicators; teacher influence, personal attitude, Montessori's material influence, and classroom condition. The data is analysed by using SPSS version 22 program to obtain accurate values of the frequency, mean and standard deviation adapted from Rahman (2018).

\subsection{Observation Checklist}

The observation checklist was done to collect quantitative data. Before collecting the data, the researcher had done check the validity of the indicators in observation checklist by using expert judgment on Thursday, May $9^{\text {th }}, 2019$. The researcher discussed it with two English teachers in Royal Prime Montessori Elementary School Pekanbaru. From the discussion, the teacher asked to revise the question number 10. So, the researcher revised it based on teacher's suggestion. After that, the researcher showed the revision and asked for teacher approval.

The form of observation checklist was nonparticipant observation because the researcher did not join in learning activity. This instrument also used likert scale that consist of five choices; very good, good, enough, less, and poor. So, the researcher able to select one of the choices based on the researcher observation in English learning activity. In addition, the researcher observed the students' activities, wrote some notes, and took documentation during observation.

$$
P=\frac{\text { Score of each indicator }}{\text { Total score }} \times 100 \%
$$

In collecting the data, the researcher collaborated with all of English teacher at Royal Prime Montessori School Pekanbaru. It happened because the researcher needs teachers help and information about the students. The data was analysed by using the percentage formula displayed in figure 3.1.

Table 3.1 The Criteria of Questionnaire Range

\begin{tabular}{cclll}
\hline \multicolumn{2}{c}{ Scale } & \multirow{2}{*}{ Scale Range } & Score & Mean Range \\
\cline { 1 - 2 }$(+)$ & $(-)$ & & & \\
4 & 1 & Absolutely agree & Highest & $4.50-5.00$ \\
3 & 2 & Agree & High & $3.50-4.49$ \\
2 & 3 & Disagree & Low & $2.50-3.49$ \\
1 & 4 & $\begin{array}{l}\text { Absolutely } \\
\text { disagree }\end{array}$ & Lowest & $1.00-2.49$ \\
\hline
\end{tabular}

(Rahman, 2018) 
The researcher also used categories to investigate the level of each factors in influencing students motivational condition in Montessori English class influence students motivational condition. The range of score is represented in table 3.1 .

\section{Findings}

From the results of the questionnaire and observation, this study determined that there are five factors that influence the enthusiasm that students display in Montessori classes. These five factors include the teacher's influence, the student's personal attitude, the Montessori material, the condition of the classroom, and the influence of the students' friends or peers.

\subsection{The Teacher's Influence}

The first factor, the teacher, has an overall mean of 3.50. The value indicates that the teacher has a high level of influence on the students' motivation.

Table 4.1 The Frequency, Mean, and Standard Deviation of the Teacher's Influence

\begin{tabular}{|c|c|c|c|c|c|c|}
\hline \multirow[t]{2}{*}{ Statements } & \multicolumn{4}{|c|}{$\begin{array}{c}\text { Response Distribution } \\
(\%)\end{array}$} & \multirow[t]{2}{*}{ Mean } & \multirow[t]{2}{*}{ SD } \\
\hline & $\mathbf{A A}$ & $\mathbf{A}$ & D & AD & & \\
\hline $\begin{array}{l}\text { My teacher } \\
\text { seldom } \\
\text { gives me } \\
\text { the chance } \\
\text { to express } \\
\text { my } \\
\text { thoughts or } \\
\text { feelings } \\
\text { during the } \\
\text { lesson }\end{array}$ & 0 & 9.1 & 43.6 & 47.3 & 3.38 & 0.652 \\
\hline $\begin{array}{l}\text { I listen } \\
\text { attentively } \\
\text { when the } \\
\text { teacher } \\
\text { presents the } \\
\text { material }\end{array}$ & 67.3 & 30.9 & 1.8 & 0 & 3.65 & 0.517 \\
\hline $\begin{array}{l}\text { I'm bored } \\
\text { when the } \\
\text { teacher } \\
\text { presents the } \\
\text { material }\end{array}$ & 0 & 0 & 52.7 & 47.3 & 3.47 & 0.504 \\
\hline
\end{tabular}

The majority of the students agreed that teacher gives them opportunity to express their thoughts or feelings in Montessori English class (My teacher seldom gives me opportunity to express my thought or feeling in English lesson). In addition, Most of them also interested to listen attentively to the teacher when teacher explain the lesson using Montessori material in English class (I am interested to listen attentively when teacher presents Montessori's materials to teach English lesson). They are also enjoyed the learning activity and never bored when teacher explain the lesson using Montessori material (I am bored when teacher presents Montessori's materials to teach English lesson).

4.2 Personal Attitude's Influence The second factor, the students' personal attitude, has an overall mean of 3.52. The value indicates that the students have displayed eagerness in the lessons.

Table 4.2 The Frequency, Mean, and Standard Deviation of Personal Attitude

\begin{tabular}{|c|c|c|c|c|c|c|}
\hline \multirow[t]{2}{*}{ Statements } & \multicolumn{4}{|c|}{$\begin{array}{c}\text { Response Distribution } \\
(\%)\end{array}$} & \multirow[t]{2}{*}{ Mean } & \multirow[t]{2}{*}{ SD } \\
\hline & $\mathbf{A A}$ & $\mathbf{A}$ & D & AD & & \\
\hline $\begin{array}{l}\text { I'm happy } \\
\text { learning } \\
\text { English in } \\
\text { Montessori } \\
\text { class }\end{array}$ & 70.9 & 29.1 & 0 & 0 & 3.71 & 0.458 \\
\hline $\begin{array}{l}\text { I think } \\
\text { English is } \\
\text { difficult }\end{array}$ & 0 & 0 & 63.6 & 36.4 & 3.36 & 0.485 \\
\hline $\begin{array}{l}\text { I always } \\
\text { speak English } \\
\text { with my } \\
\text { teacher and } \\
\text { friends }\end{array}$ & 74.5 & 25.5 & 0 & 0 & 3.75 & 0.440 \\
\hline $\begin{array}{l}\text { I'm nervous } \\
\text { to speak } \\
\text { English in } \\
\text { school }\end{array}$ & 0 & 3.6 & 58.2 & 38.2 & 3.35 & 0.552 \\
\hline $\begin{array}{l}\text { I prefer to } \\
\text { speak English } \\
\text { in school }\end{array}$ & 0 & 0 & 25.5 & 74.5 & 3.75 & 0.440 \\
\hline $\begin{array}{l}\text { I prefer to } \\
\text { talk with my } \\
\text { friends than } \\
\text { listening to } \\
\text { the teacher } \\
\text { during } \\
\text { lessons }\end{array}$ & 0 & 0 & 34.5 & 65.5 & 3.65 & 0.480 \\
\hline $\begin{array}{l}\text { I always try } \\
\text { to finish the } \\
\text { assignment } \\
\text { independently }\end{array}$ & 72.7 & 27.3 & 0 & 0 & 3.73 & 0.449 \\
\hline $\begin{array}{l}\text { I often give } \\
\text { up when I } \\
\text { cannot finish } \\
\text { my } \\
\text { assignment }\end{array}$ & 1.8 & 0 & 74.5 & 23.6 & 3.20 & 0.524 \\
\hline $\begin{array}{l}\text { I'm often } \\
\text { confused } \\
\text { about the } \\
\text { conclusion of } \\
\text { each } \\
\text { Montessori } \\
\text { English class }\end{array}$ & 0 & 12.7 & 56.4 & 30.9 & 3.18 & 0.641 \\
\hline
\end{tabular}


All of students were happy learn English in Montessori class (I am happy learning English in Montessori class). They also think that English was not difficult for them (I think English is difficult). In addition, they were always confidence to speak English with their teacher and friends in daily ( $I$ always speak English with my teachers and friends) and (I am nervous to speak English in the school).

Moreover, they enjoyed to learn English in Montessori class, they prefer to study and listen to the teacher rather than sleep or disturb their friends ( $I$ prefer to sleep rather than study in Montessori class) and (I prefer to disturb my friends rather than listen to the teacher). Moreover, all of them were enthusiast and never give up to finish their assignment in Montessori English class (I always try to finish the assignment independently) and (I often give up when I cannot finish my assignment). Furthermore, most of students always understood of the English lesson in Montessori class (I often confuse about the conclusion of each English lesson in Montessori class).

\subsection{Montessori Materials' Influence}

The result of the questionnaire showed that Montessori's lesson materials have a high influence in motivating students in English Montessori class by a mean of 3.608 .

Table 4.3 The Frequency, Mean, and Standard Deviation of Montessori Materials' Influence

\begin{tabular}{|c|c|c|c|c|c|c|}
\hline \multirow[t]{2}{*}{ Statements } & \multicolumn{4}{|c|}{$\begin{array}{c}\text { Response Distribution } \\
(\%)\end{array}$} & \multirow[t]{2}{*}{ Mean } & \multirow[t]{2}{*}{ SD } \\
\hline & $\mathbf{A A}$ & $\mathbf{A}$ & D & AD & & \\
\hline $\begin{array}{l}\text { I enjoy use } \\
\text { Montessori's } \\
\text { materials in } \\
\text { English } \\
\text { class } \\
\text { because it } \\
\text { can develop } \\
\text { my } \\
\text { intelligence }\end{array}$ & 54.5 & 45.5 & 0 & 0 & 3.55 & 0.503 \\
\hline $\begin{array}{l}\text { I think } \\
\text { Montessori's } \\
\text { materials do } \\
\text { not help me } \\
\text { to } \\
\text { understand } \\
\text { the lesson }\end{array}$ & 0 & 0 & 65.5 & 34.5 & 3.35 & 0.480 \\
\hline $\begin{array}{l}\text { Montessori's } \\
\text { materials } \\
\text { stimulate my } \\
\text { desire to } \\
\text { follow } \\
\text { teacher's } \\
\text { instruction }\end{array}$ & 72.7 & 27.3 & 0 & 0 & 3.73 & 0.449 \\
\hline
\end{tabular}

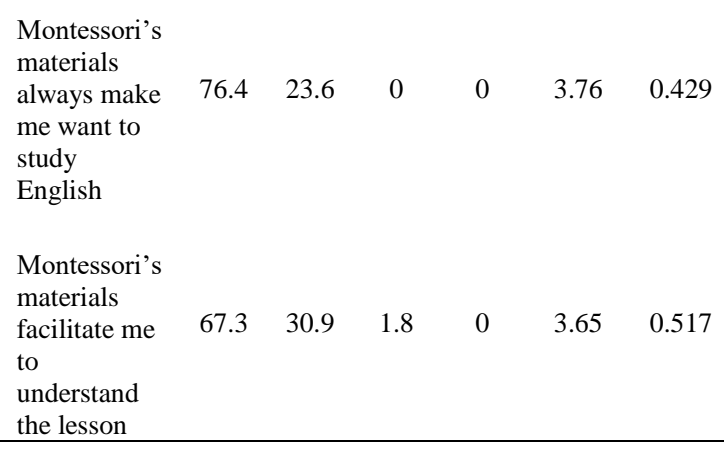

All of students enjoy to use Montessori's materials in English class because it helped them to understand the lesson and develop their intelligence (I enjoy use Montessori's materials in English class because it can develop my intelligence). They are also agreed that Montessori material can help them to understand the lesson (I think Montessori's materials do not help me to understand the lesson). Beside it, most of them stated that Montessori's materials make them enthusiast to listen and follow teachers instruction (Montessori's materials stimulate my desire to follow teacher's instruction). Most of them also said that Montessori's materials are able to stimulate their desire to learn English in Montessori class (Montessori's materials always make me want to study English). Moreover, Most of them agreed that Montessori's materials as good facilitate which help them to understand the lesson (Montessori's materials facilitate me to understand the lesson)

\subsection{Classroom Condition's Influence}

The findings indicated that the condition of the classroom has a high influence in motivating students in English Montessori class by a mean of 3.54.

Table 4.4 The Frequency, Mean, and Standard

Deviation of Classroom Condition's Influence

\begin{tabular}{|c|c|c|c|c|c|c|}
\hline \multirow[t]{2}{*}{ Statements } & \multicolumn{4}{|c|}{$\begin{array}{c}\text { Response Distribution } \\
(\%)\end{array}$} & \multirow[t]{2}{*}{ Mean } & \multirow[t]{2}{*}{ SD } \\
\hline & $\mathbf{A A}$ & $\mathbf{A}$ & D & AD & & \\
\hline $\begin{array}{l}\text { Montessori } \\
\text { class } \\
\text { stimulates } \\
\text { me to } \\
\text { express my } \\
\text { thought or } \\
\text { feeling in } \\
\text { English } \\
\text { lesson }\end{array}$ & 61.8 & 36.4 & 1.8 & 0 & 3.60 & 0.531 \\
\hline $\begin{array}{l}\text { I am } \\
\text { nervous to } \\
\text { express my } \\
\text { thought or } \\
\text { feeling in } \\
\text { Montessori } \\
\text { class }\end{array}$ & 0 & 3.6 & 52.7 & 43.6 & 3.40 & 0.564 \\
\hline
\end{tabular}




\begin{tabular}{|c|c|c|c|c|c|c|}
\hline $\begin{array}{l}\text { the clean } \\
\text { and tidy } \\
\text { class makes } \\
\text { me enjoy to } \\
\text { learn }\end{array}$ & 65.5 & 34.5 & 0 & 0 & 3.65 & 0.480 \\
\hline $\begin{array}{l}\text { I enjoy in } \\
\text { the class } \\
\text { that hot and } \\
\text { dirty }\end{array}$ & 0 & 0 & 49.1 & 50.9 & 3.51 & 0.505 \\
\hline
\end{tabular}

Most of students agreed that they are confidence and capable to express their thought and feeling in Montessori English class (Montessori class stimulates me to express my thought or feeling in English lesson) Moreover, they also agreed that clean and tidy class influence their condition during learning activities (The clean and tidy class makes me enjoy to learn) From the data above, we can stated that classroom condition give the contribution on students' motivation in Montessori English class.

Moreover, the researcher observed the primary 1-5 students learning activity in Montessori English class on May, $10^{\text {th }}-16^{\text {th }} 2019$. The researcher used nonparticipant observation because the researcher did not join in the learning activities. The researcher also used 5 scales to investigate the percentage of the students' responses in Montessori English class progression. The researcher used 10 indicators to observe students' responds in learning activity. Based on the finding, the students showed high enthusiasm to respond in the learning activities in English Montessori classroom.

Table 4.5 The Percentage of Observation Checklist

\begin{tabular}{lll}
\hline \multicolumn{1}{c}{ Indicators } & \multicolumn{1}{c}{$\begin{array}{c}\text { Response } \\
\text { Distribution } \\
\text { (\%) }\end{array}$} & Note \\
\hline $\begin{array}{l}\text { Students are interest to start the } \\
\text { lesson }\end{array}$ & $98 \%$ & Highest \\
$\begin{array}{l}\text { Students listen attentively to the } \\
\text { teacher when teacher introduce the } \\
\text { lesson }\end{array}$ & $92 \%$ & Highest \\
$\begin{array}{l}\text { Students are enthusiast to follow } \\
\text { teacher's instruction }\end{array}$ & $89 \%$ & Highest \\
$\begin{array}{l}\text { Students are enthusiast to use } \\
\text { Montessori's material }\end{array}$ & $90 \%$ & Highest \\
$\begin{array}{l}\text { Students are able to respond } \\
\text { teacher's questions }\end{array}$ & $90 \%$ & Highest \\
$\begin{array}{l}\text { Students are able to make or } \\
\text { mention other examples } \\
\text { Students are able to finish the } \\
\text { assignment }\end{array}$ & $85 \%$ & Highest \\
$\begin{array}{l}\text { Students are able to correct the } \\
\text { mistakes }\end{array}$ & $82 \%$ & Highest \\
$\begin{array}{l}\text { Students will ask the teacher if they } \\
\text { do not understand the lesson }\end{array}$ & $89 \%$ & Highest \\
$\begin{array}{l}\text { Students are able to give their own } \\
\text { conclusion about the lesson }\end{array}$ & $94 \%$ & Highest \\
\hline
\end{tabular}

Table 4.5 indicated that $98 \%$ of students are enthusiastic to join in English Montessori class. The researcher noted that most of students responded to the teacher when teacher opened the class and asks students' condition. For example, primary 1 student; Xresponds to the teacher when teacher opens the class and asks students' condition. The researcher also looked that only one students at primary 5 that do not respond to the teacher when teacher open the class $\mathrm{X}$ do not respond to the teacher when teacher open the class. He just looked at the teacher and his friends. He was also too clearly busy with himself.

$92 \%$ of students are enthusiastic to listen and participate in the lessons. The researcher noted that most of students were listening and responding to the teacher when teacher opened the lesson. For example, most of primary 2 students were also able to listen and respond the teacher when teacher guide them to know what is adverb and the type of adverb. For example, $\mathrm{X}$ listens and responds when teacher guide them to know what is adverb and mention the type of adverb together. The researcher also saw that only some students do not really listen and respond to the teacher when teacher introduce the lesson; one students at primary 1,2,3,4 and five students at primary 5. For example one student at primary 1 do not focus when the teacher opened the lesson. He seems busy with his eraser.

$89 \%$ of students are enthusiastic to listen and followed teacher's instruction. The researcher noted that most of students were enthusiast to listen and respond teacher's instruction. Most of primary 3 students were able to listen and respond when teacher guide them to analyze the example and give the instruction to finish the assignment. For example; $\mathrm{X}$ listen and respond when teacher give the example and the instruction to finish the assignment. The researcher looked that only some of them do not really listen and respond teacher's instruction; one students at primary 4 and six students at primary 5 . For example, $\mathrm{X}$ do not listen and respond the teacher.

$90 \%$ of students are enthusiast to use Montessori's materials. They were enthusiast to identify each material, make and analyse the sentence by using the materials. The researcher noted that most of students were enthusiast to listen to the teacher's instruction about the lesson and finish their assignment by using the materials. Most of primary 3 students were able to arrange and analyse the sentence by using the words inside the grammar box. They were also able to analyse part of speech in each sentence. For example; $\mathrm{X}$ is enthusiast to make 5 sentences by using the words inside the grammar box, place it on the grammar filler box and arrange it on the table. The researcher saw that only some of them did not listen and respond teachers' instruction to use the materials; one student at primary 1,4 and three students at primary 5. For example, Xdo not pay attention when teacher guides them to analyse the sentences by using the symbols. 
$90 \%$ of students are enthusiast to respond teacher's questions and instruction. The researcher noted that most of them were enthusiast to respond teacher's questions and instruction in learning activity. Most of primary 4 students were able to respond teachers question and instruction to identify each symbol, make and analyse the sentence together. For example, $\mathrm{X}$ responded teacher's instruction to mention the name of each symbol, make and analyse the sentence by using the materials. The researcher also looked that only some of them did not respond to the teacher's questions and instruction; one student at primary 4 and four students at primary 5. For example, $\mathrm{X}$ do not respond to the teacher question. She just paid quiet attention to the teacher.

$85 \%$ of students are enthusiast to make or analyse the examples. The researcher noted that most of students at primary 4 were able to make the sentence. For example, Xtries to make the sentences based on the symbol that teacher gave. The researcher saw that only some students did not try to make or analyse the examples; one student at primary 2 , three primary 4 students and six primary 5 students. For example, Xdo not try to analyse the example.

$92 \%$ of students are able to finish the assignment. The researcher noted that most of them are able to make and analyse the sentences independently or in a group. Most of primary 5 students were able to make and analyse the sentence by making a syntax tree in a group. For example, X's group is able to make and analyse the sentence by making a syntax tree. The researcher also saw that only some students are able to finish their assignment with teacher guidance. For example, $\mathrm{X}$ is able to make a sentence and place it in each arrow with teacher guidance.

$88 \%$ of students were able to analyse the assignment together by using the materials. They had no problem when analysed the assignment by using the materials. Most of primary 2 students were able to place each word by answer the questions in each arrow. They are also able to correct their mistake when the answer is not suitable with the question. For example; Xtry to analyse the sentence by place each word in each arrow. The researcher saw that only some of them did not try to analyse the assignment; one student at primary 3, 4 and four students at primary 5. They paid attention when teacher guided them to analyse the assignment but do not respond it. For example, X do not try to analyse other group's sentences.

$89 \%$ of students are confident and brave enough to ask the teacher if they are confused or do not understand the lesson. A primary 4 student, X, asked the teacher, "is it article or conjunction and what is conjunction?" Almost all of them were able to create and analyse the sentences in materials. They were able to respond and follow the teacher's instruction.
The researcher also saw that only a few students were not one hundred per cent engaged in the class.

$94 \%$ of students are able to give their own conclusion about the lesson. The researcher observed that most of them were able to understand and follow the lesson. They were able to identify each symbol or material. They were also able to mention some example, make the sentences, finish their assignment and analyze or discuss the assignment by using the materials with the teacher. The researcher saw that some of them needed teacher guided to understand the lesson.

\section{Discussion}

As explained previously, this research was carried out in five classes and the researcher used total sampling with 55 students as the sample. This research conducted at the primary 1-5 students in Royal Prime Montessori Elementary School Pekanbaru. The purposes of this research were to investigate factors in Montessori English class that influence students motivational condition and to describe how students' responds during learning activities in Montessori English class.

Based on the data questionnaire, it found that factors influence students motivation in Montessori class were in teacher influence, personal attitude, Montessori's material and classroom influence. Teacher's way to present the lesson and manage the class will determine students' condition and performance in learning activities. Then, students' attitude toward English class will give the impact for students' achievement in the class. Moreover, Montessori material also influences students' curiosity and enthusiast to finish the assignment or understand the lesson. When the material facilitates them easy to understand the lesson, the students will interest to be active in the class. Furthermore, classroom condition influence students condition in the class. The students will happy and enjoy to join the class if the class is clean, big, and tidy.

Based on the data observation, it found that most of students are enthusiast to join in Montessori English class. Teacher's way and material contribution makes them enthusiast to respond and listen to the teacher when teacher present the lesson by using the materials. Montessori material makes the students be active in the class. The materials are able to stimulate students' interest and curiosity to listen and follow teacher instruction and finish their assignment. It happened because the material is concrete and unique. So, the students easily to understand the lesson.

The finding is almost similar with the research by Adisti (2018) which showed that the application of Montessori method to teach English for young learner is able to stimulate students interest and enthusiasm in 
learning activities. Students also enjoy and become more active during learning activities. Montessori values are also able to make students be responsible and more creative so the students will not bored during learning activity. The differences in this research is the impact after apply Montessori method to teach English for young learner.

Then, related to the implementation of Montessori method to teach English by Handayani (2014)which had a different aim, the result from this study showed that Montessori has been proven to be very effective and functional to teach English for young learner. The implementation of Montessori method is to make children to be bilingual, creative, and competence individual, also to be sociable and responsible person. Moreover, the finding is also similar Faryadi's (2011) whose research showed that students in Montessori classroom environment were most excited to learn English in a fun way. Sensory method in Montessori class significantly improved students' performance as well as motivated them to learn and continue learning the English Language.

\section{Conclusion}

Based on the findings of this study, the researcher concluded that the huge majority of the young learners in Royal Prime Montessori Elementary school are highly motivated in English learning activities. The Montessori materials, classroom condition, the teachers, the students' friends and personal attitude are significant factors on their overall learning motivation.

\section{References}

Derin, T., \& Hamuddin, B. (2019). Foreign Language Classroom Anxiety, and Enjoyment During Study Abroad: A Review of Selected Paper. Lisan: Jurnal Bahasa dan Linguistik, 8(2), 76-82. https://doi.org/10.33506/li.v8i2.367

Nasution, A. K. R. (2019). YouTube as a media in English language teaching (ELT) context: Teaching procedure text. Utamax: Journal of Ultimate Research and Trends in Education, 1(1), 29-33. https://doi.org/10.31849/utamax.v1i1.2742

Akhsanova, L. N., \& Salyakhova, G. I. (2016). English teaching features on the basis of Montessori system among preschool age children (working experience). International Journal of Humanities and Cultural Studies (IJHCS) ISSN 2356-5926, 1(1), 758-764.

Aliaga, M. \& Gunderson, B. 2000. Interactive Statistics. New York-Pearson Prentice Hall.

Alizadeh, M. (2016). The impact of motivation on English language learning. International
Journal of Research in English Education, 1(1), 11-15.

Arikunto, S. 2013. Prosedur Penelitian: Suatu Pendekatan Praktik. Jakarta-Rineka Cipta.

Junaidi, Budianto Hamuddin, Kenny Julita, Fathu Rahman, Tatum Derin. (2020). Artificial Intelligence in EFL Context: Rising Students' Speaking Performance with Lyra Virtual Assistance. International Journal of Advanced Science and Technology, 29(05), 6735 - 6741. Retrieved from http://sersc.org/journals/index.php/IJAST/arti cle/view/17726

Faryadi, Q. (2009). Performance evaluation of Montessori instruction to teach English as a second Language: An experimental research. MASAUM Journal of Open Problems in Science and Engineer-ing, 1(2), 81-85.

Goss, P., \& Sonnemenn, J. (2017). Engaging students: Creating classrooms that improve learning.

Habibi, A., Sofwan, M., \& Mukminin, A. M. I. R. U. L. (2016). English teaching implementation in Indonesian pesantrens: teachers' demotivation factors. Indonesian Journal of English Teaching, 5(2), 199-213.

Handayani, S. (2014). The Implementation Of Comprehensive Montessori Method For The Teaching Of English Language At Singapore Piaget Academy International School Solo Baru (Doctoral dissertation, Universitas Muhammadiyah Surakarta).

Harjali, H. (2018). Meaning of Developing Student Centered Classroom Environment. JPI (Jurnal Pendidikan Indonesia),6(2), 134140.

Kay1l, G. (2018). The effect of Montessori method on cognitive tempo of kindergarten children. Early Child Development and Care, 188(3), 327-335.

Long, C., Ming, Z., \& Chen, L. (2013). The Study of Student Motivation on English Learning in Junior Middle School--A Case Study of No. 5 Middle School in Gejiu. English Language Teaching, 6(9), 136-145.

Mcinerney, D. M., \& Liem, A. D. (2008). Motivation theory and engaged learning. In Motivation and practice for the classroom (pp. 9-36). Brill Sense.

Rahman, F. (2018). The Constraints of Foreign Learners in Reading English Literary Works: A Case Study at Hasanuddin University. Journal of Arts and Humanities, 7(2), 01-12. 
Salazar, M. (2014). The impact of Montessori teaching on academic achievement of elementary school students in a Central Texas school district: a causal-comparative inquiry (Doctoral dissertation).

Scanlan, P. (2013). Respectful relationships: how does the Montessori environment foster relationships with respect? (Doctoral dissertation, Auckland University of Technology).

Suprijono, A. (2009). Cooperative learning: teori \& aplikasi PAIKEM. Pustaka Pelajar.

Hamuddin, B., Syahdan, S., Rahman, F., Rianita, D., \& Derin, T. (2019). Do They Truly Intend to Harm Their Friends?: The Motives Beyond Cyberbullying among University Students. International Journal of Cyber Behavior, Psychology and Learning (IJCBPL), 9(4), 32-44. https://doi.org/10.4018/IJCBPL.2019100103

Tanner, C. K. (2000). The influence of school architecture on academic achievement. Journal of educational administration

Wekke, I. S., Yandra, A., \& Hamuddin, B. (2017, December). Learning Strategy in Class Management: A Reflection from Manado Case. In IOP Conference Series: Earth and Environmental Science (Vol. 97, No. 1, p. 012053). IOP Publishing 